\title{
Inventorying, Mapping and Monitoring of Mangroves towards Sustainable Management of West Coast, India
}

\author{
Prakash N Mesta ${ }^{1}$, Bharath Setturu1,3, Subash Chandran MD ${ }^{1}$, Rajan KS ${ }^{3}$ and Ramachandra TV ${ }^{1,2 *}$ \\ ${ }^{1}$ Energy and Wetlands Research Group, Centre for Ecological Sciences [CES], Indian Institute of Science, Bangalore, Karnataka, 560012, India \\ ${ }^{2}$ Center for Sustainable Technologies (astra), Indian Institute of Science, Bangalore 560 012, India \\ ${ }^{3}$ International Institute of Information Technology-Hyderabad [IIIT-H], India
}

\begin{abstract}
Mangroves are one of the productive and highly adaptive ecosystems on the Earth, and provide invaluable services to the coastal communities. Ecological and sustainable management of the mangrove ecosystem requires crucial knowledge of variability and dynamics over a time and space. There are no reliable recent spatial extent estimates of mangroves or trend of coverage in West coast. The mapping from medium spatial resolution remote sensing data often leads to the underestimation of spatial extent. An attempt has been made to provide detailed information of mangroves species distribution using remote sensing data of high spatial resolution integrated with the other collateral field information through GIS. The coastline changes and the mangrove dynamics during 1989-2010 were assessed using supervised classifier technique provided the spatial distribution of mangrove species namely Rhizophora mucronata, Sonneratia caseolaris, Avicennia officinalis, Sonneratia alba, and Kandelia cande/ with classification good accuracy. Delineation of mangroves at species wise records based on extensive field data will be invaluable for appropriate management (e.g. plantation, eco-tourism) and conservation measures for estuaries of Central Western Ghats. Mangroves play pivotal role in providing vital ecosystem goods and services, but are under threat due to anthropogenic activities, affecting habitat for specialised fauna and food resources for humans, birds and fish. This necessitates interventions of regulatory authorities to partner with the local communities in the restoration and conservation of mangrove habitats.
\end{abstract}

Keywords: Mangroves; Remote sensing; Vegetation transition; Estuaries; Coastal management; Species distribution

\section{Introduction}

Mangroves maintain high level of biological productivity of coasts and estuaries through sequestering carbon and recycling of nutrients throughout the year. Mangroves cover about $8 \%$ of the world vegetation and play a vital role in the productivity of global ecosystem [1], found along the tropical and subtropical coasts of Australia, Asia, Africa and the America [2]. Mangrove shorelines occur in diverse environmental settings of geophysical (climate, tides and sea level) and geomorphological (dynamic history of the land surface and contemporary processes and biological components) [3]. Mangroves and its associated ecosystems are biologically most productive, socioeconomically important, and aesthetically attractive while providing food and shelter for many vital biotic species some are commercially very important [4,5]. Mangroves support local as well as global communities through a wide variety of ecosystem goods (fuel wood, medicine, construction materials) and services (shoreline stabilization, fisheries breeding and nursery grounds, sedimentation trapping, uptake of nutrients and heavy metals-phytoremediation) having immense value [6]. The value of an estuary is accounted as $\$ 19120 /$ $\mathrm{Ha}$ /year by aggregation of all goods and services such as shrimps, fish, crabs, salt, mangroves, in addition to services such as fish spawning grounds, nutrient cycling, hydrology, flood control, soil protection, sink for carbon etc. [7]. As per the earlier estimates [8] economic value of mangroves varies between $\$ 200 \mathrm{k}$ and $\$ 900 \mathrm{k}$ per $\mathrm{km}^{2}$ per year depending on the geographical regions. Mangroves sequester and store carbon stocks and hence the global organizations have focused their attention with conservation measures [9,10]. Mangrove soils and roots also act as a reservoir which sequesters an additional carbon.

Dependency of local communities has been traditional and sustainable; however in recent times during the post globalisation era mangroves are facing serious threats due to over harvesting of coastal resources due to the rapid growth of population, migration into the coast, industrialization the sustained inflow of sewage (domestic) and effluents (industries) [11], large scale topographical and hydrological alterations etc. [12]. In addition to the lack of appropriate regulatory mechanisms to implement the coastal zone norms and land use land cover (LULC) changes due to socio-economic consequences have contributed to the sharp decline of mangrove cover [13,14]. Rampant expansion of aquaculture farms and the demand of hard wood in construction sector have led to the removal of mangroves [15-17]. This emphasises the need for integrated approaches involving inventorying, mapping and monitoring including sustainable resource management with land-use planning for conservation based decision making. Species and landscape level information of mangroves is required for a thorough understanding of mangrove biodiversity for an effective management [18-20]. Temporal remote sensing (RS) data acquired through space-borne sensors at regular intervals since 1970's with geographic information system (GIS) provide a reliable and cost effective as well as alternative technique for mapping and management of the coastal habitats. Remote sensing data with GIS and collateral data add further information for the accurate, detailed and cost effective spatial information $[21,22]$ as well to visualize the predicted scenarios based on various policy prerogatives for economic and social sustainability

*Corresponding author: Ramachandra TV, Energy and Wetlands Research Group, Centre for Ecological Sciences [CES], Indian Institute of Science, Bangalore, Karnataka, 560 012, India, Tel: 91-80- 22933099/22933503; Fax: 9180-23601428; E-mail: cestvr@ces.iisc.ernet.in

Received July 22, 2014; Accepted August 30, 2014; Published September 04, 2014

Citation: Mesta PN, Setturu B, Subash Chandran MD, Rajan KS, Ramachandra TV (2014) Inventorying, Mapping and Monitoring of Mangroves towards Sustainable Management of West Coast, India. J Geophys Remote Sensing 3: 130. doi:10.4172/2169-0049.1000130

Copyright: ( 2014 Mesta PN, et al. This is an open-access article distributed under the terms of the Creative Commons Attribution License, which permits unrestricted use, distribution, and reproduction in any medium, provided the original author and source are credited. 
in the coastal zone $[23,24]$. Improvements in the development of free and open source software have emerging as an alternative approach for a wide range of applications with multiple data formats $[25,26]$. Recent advances in sensor technologies (e.g., IRS, IKONOS, and QuickBird) have enhanced the ability of RS programme to provide multi-resolution data. RS data are supplemented with different types of collateral vector data and environmental attributes and spectral information $[27,28]$ for high precision mapping. Collection of ground control points [29] and training polygons using global positioning system (GPS) helps in the geo-registration, classification and accuracy assessment [30]. Data of Landsat series has limitations due to the coarse spatial resolution has often resulted in the underestimation of mangrove areas at locations where the spatial coverage is relatively small and fragmented [29-33]. Complex tropical atmospheric conditions, high spatial variability further pose challenges in the selection of sensors and appropriate data analysis methods. The spectral separation of mangrove vegetation has been carried out through various classification algorithms [34,35]. Among many techniques, supervised classification technique is considered as most effective scheme, because it is based on statistical identification function according to typical sample training methods. Application of the supervised Gaussian maximum likelihood classifier (GMLC) was proved to be the robust method for classifying mangroves [35-38]. Inventorying, temporal mapping would provide valuable information pertaining to the spatial distribution, heterogeneity and its variability for effective monitoring and ecologically sound management of coastal ecosystems.

\section{Objectives}

Main objective is the inventorying and mapping of mangroves. This involves

- The determination of the spatial extent, status of mangroves using remote sensing data;

- $\quad$ Mapping of mangrove distribution at species level; and

- Investigation of vegetation dynamics in the estuarine landscape during 1989 to 2010 .

\section{Material and Methods}

\section{Study area}

This study has been carried out in estuarine or brackish water environment of Bhatkal, Honnavar, Kumta and Ankola (partially) taluks of Uttara Kannada district in the west coast of India, located between $13^{\circ} 55^{\prime} 15^{\prime \prime}$ to $14^{\circ} 36^{\prime} 3^{\prime \prime} \mathrm{N}$ and, $74^{\circ} 17^{\prime} 9^{\prime \prime}$ to $75^{\circ} 45^{\prime} 32^{\prime \prime} \mathrm{E}$ (Figure 1). The region falls under the administrative jurisdiction of Honnavar forest division of Karnataka Forest Department. This region has gentle undulating hills, rising steeply from a narrow coastal strip bordering the Arabian Sea. Four major rivers Aghanashini, Gangavali, Sharavati and Venkatapura have their sources in the Sahyadri (Mountainous part of Western Ghats) and flow west through this region into the Arabian Sea. This region is having long stretch of dense and tall mangrove vegetation along the coast with a high number of mangrove plant species. Mangrove plants are locally known as Kandla or Sundari. In the district, planting of mangrove saplings took place post 1990's with public and forest department participation. This sequence of activities at all estuaries has led to enhancement in mangrove cover of district. The constant blending and circulation of fresh water flow from one side, the tidal influx from the Arabian Sea oxygenates the water and circulates nutrients in these estuaries standing as high productive among west coast. The rich mangrove vegetation has significant role in food supply and act as a protective nurseries even for many species of marine fishes and prawns [39]. The major economic activity of this region is fishing, agriculture and horticulture. Fishery sector has been playing a crucial role in the economy of the district. Forests also play a significant role in economy and the region's forest cover varies from semi-evergreen to evergreen and also with moist deciduous forests. This region is well known for the production of coconut, pepper, cardamom, cashew and areca nuts. The average rainfall ranges from 3009 to $4339 \mathrm{~mm}$ [40] (Figures 1a and 1b).

\section{Remote sensing (RS) data}

The RS data used in the study include Landsat TM (1989), Landsat ETM+ (2003), IRS LISS-IV MX (2010), and Google Earth (http://earth. google.com). The Landsat data (a series of earth resource scanning satellites launched by the USA) is cost effective, with high spatial resolution and freely downloadable from public domains like Global Land Cover Facility (GLCF) (http://glcfapp.glcf.umd.edu:8080/esdi/ index.jsp) and United States Geological Survey (USGS) (http://glovis. usgs.gov/). In this work, moderate spatial resolution remote-sensed imagery were employed, such as Landsat TM and ETM+ with high resolution IRS (Indian Remote Sensing Satellite system-launched in the course of the Indian Space Programme) L4MX data. The characteristics of datasets used are summarized in Table 1.

\section{Ancillary data}

The prime use of ancillary data is to get assistance in the interpretation of different land use types from remotely sensed images.

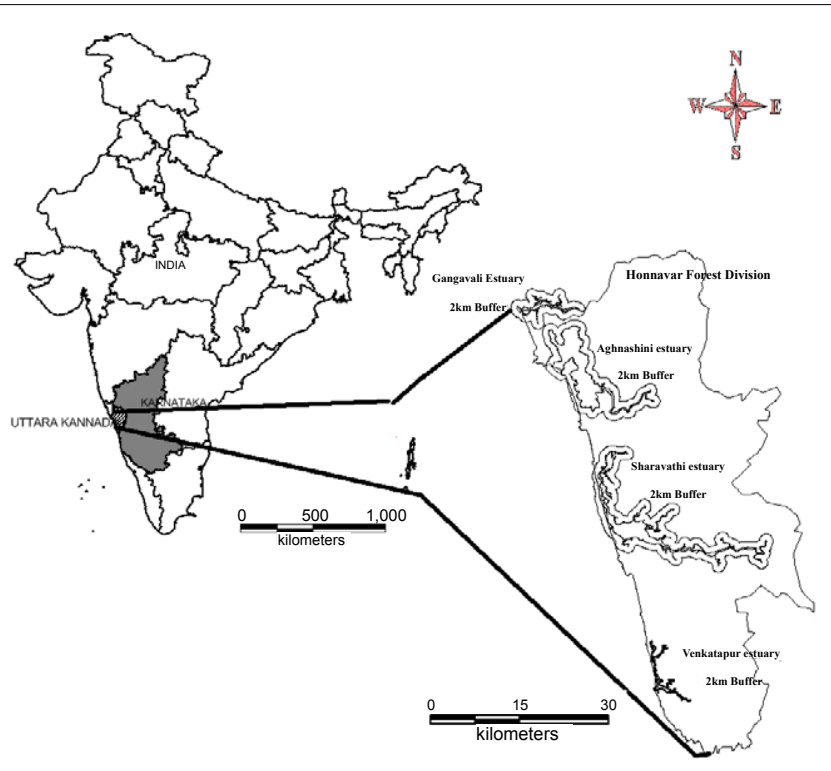

Figure 1a: Study area.

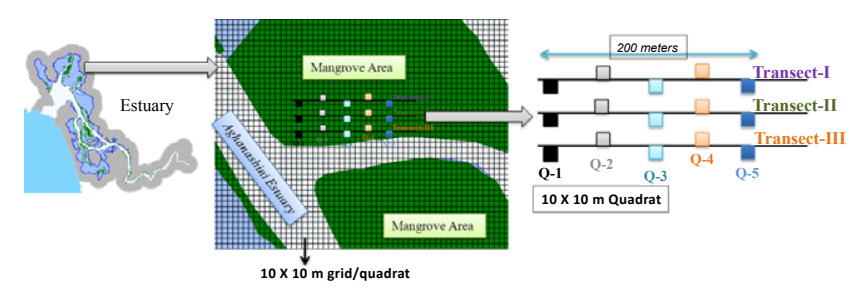

Figure 1b: Field measurement and data collection. 
Citation: Mesta PN, Setturu B, Subash Chandran MD, Rajan KS, Ramachandra TV (2014) Inventorying, Mapping and Monitoring of Mangroves towards Sustainable Management of West Coast, India. J Geophys Remote Sensing 3: 130. doi:10.4172/2169-0049.1000130

Page 3 of 8

\begin{tabular}{|c|c|c|c|c|}
\hline Data set & Year & Resolution (M) & $\begin{array}{l}\text { Number of } \\
\text { Bands }\end{array}$ & Wavelength $(\mu \mathrm{m})$ \\
\hline Landsat TM (Thematic Mapper) & 1989,2000 & $\begin{array}{l}28.5,120 \\
\left(6^{\text {th }} \text { band }\right)\end{array}$ & 7 & $\begin{array}{l}\text { B1:0.45-0.52 } \\
\text { B2:0.52-0.60 } \\
\text { B3:0.63-0.69 } \\
\text { B4:0.76-0.90 } \\
\text { B5:1.55-1.75 } \\
\text { B6:10.4-12.5 } \\
\text { B7:2.08-2.35 }\end{array}$ \\
\hline Landsat ETM+ (Enhanced Thematic Mapper Plus) & 2003 & $\begin{array}{l}30,60\left(6^{\text {th }} \text { band }\right) \\
15\left(8^{\text {th }} \text { band }\right)\end{array}$ & 8 & $\begin{array}{l}\text { B1: } 0.45-0.52 \\
\text { B2: } 0.52-0.60 \\
\text { B3: } 0.63-0.69 \\
\text { B4: } 0.76-0.90 \\
\text { B5: } 1.55-1.75 \\
\text { B6: } 10.4-12.5 \\
\text { B7: } 2.08-2.35 \\
\text { B8: } 0.52-0.9\end{array}$ \\
\hline IRS-P6 L4 MX (Indian Remote sensing Satellite system P6 LISS 4 multi-spectral mode) & 2010 & 5 & 3 & $\begin{array}{l}\text { B2: } 0.52-0.59 \\
\text { B3: } 0.62-0.68 \\
\text { B4: } 0.77-0.86\end{array}$ \\
\hline
\end{tabular}

Table 1: Data used in the analysis.

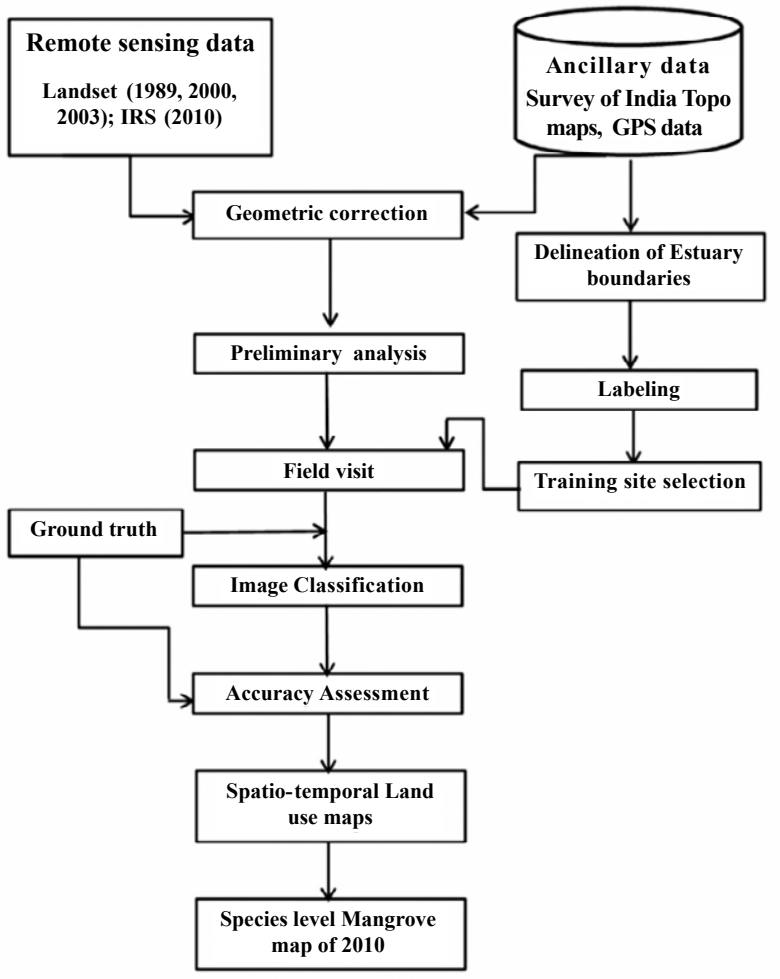

Figure 2: Flow chart of method used.

This includes Survey of India (SOI) topographical maps of scale 1:50,000 and 1:250,000, covering all taluks of Uttara Kannada district. These paper maps were digitized and geo-referenced to generate the base layers such as vector layers of taluk boundaries, drainage network, etc. These base layers were used for geometric correction of remote sensing data and training data collection (Table 1).

\section{Field survey}

The field survey of select training sites provided the attribute information of mangrove forests. Calibrated handheld GPS was used for collection of ground control points and training data. GPS calibration was done by taking the known coordinates like intersection of roads, buildings, etc. This is commonly used single step procedure which consists of extending existing adjustment procedures with additional observation equations [41]. The training data exercise provided the spatial extent and location (latitude and longitude) of different land uses. At $10 \mathrm{~m}$ intervals of each sample point, four distance limited quadrants of $5 \times 5 \mathrm{~m}^{2}$ were established with respect to the navigational direction and species wise locations and type were collected. Sampling was conducted at low tide time by placing the quadrat frames along each transect line, covering representative samples of the entire mangrove community. Transect based quadrat sampling was done to assess the species diversity, etc. Number of quadrats per transect depended on the species area curve. Transects were chosen to represent the study region and distributed uniformly all over the region, could be easily identified and located in the remote sensing data. This approach has provided good accuracy while allowing fairly rapid surveys. Transects were laid exclusively for training and validation exercises. Species level validation was done through independent validation plots. Categories exclusive and non-exclusive mangrove species were considered to determine the dominant species on the ground. Exclusive species referred to mangrove tree species that restricted to the mangrove habitat whereas non-exclusive species may be important in the mangrove habitat but which are not restricted to it. Training sites were selected for the most common species encountered in the mangrove regions. The remaining other species which did not form enough mono specific patches for training site selection are considered as other vegetation types. The site selection based on zonation of species availability, tidal condition place important role in field estimation [42]. In addition, essential ecological and botanical features of mangroves were observed and documented. The field observation, ground truth data are mainly aided to focus on locations where the landscape had been altered and land use had been changed over the past years.

\section{Method}

The method used for mapping mangroves at west coast of India (Figure 2) involves downloading cloud free, atmospherically corrected RS data of Landsat from the public domain (http://glovis. usgs.gov/) and procuring IRS (Indian Remote Sensing) data from the National Remote Sensing Centre, Hyderabad (http://nrsc.gov. in). These data were subjected to the preprocessing which includes atmospheric correction and geometric correction (for correct area measurements), precise localization and multi-source data integration $[43,44]$. Geometric correction was done by using ground control points 
collected from field survey as well as known points from topographic maps of the Survey of India. Landsat data was resampled to 30 meters to maintain common resolution across the multi resolution data.

Land use analyses involved i) generation of False Colour Composite (FCC) of remote sensing data (bands-green, red and NIR). This helped in locating heterogeneous patches in the landscape ii) selection of training polygons (these correspond to heterogeneous patches in FCC) covering $15 \%$ of the study area and uniformly distributed over the entire study area, iii) loading these training polygons co-ordinates into pre-calibrated GPS, vi) collection of the corresponding attribute data (land use types) for these polygons from the field. GPS helped in locating respective training polygons in the field. The field investigation was carried out for compilation of attribute data - mangroves species distribution at each training site, iv) supplementing this information with Google Earth v) $60 \%$ of the training data has been used for classification, while the balance is used for validation or accuracy assessment.

The land use analysis was done using supervised classification scheme of GMLC with the collected field data based on the spectral properties of features. GRASS GIS (Geographical Analysis Support System); a free and open source geospatial software with the robust functionalities for processing vector and raster data available at (http:// wgbis.ces.iisc.ernet.in/grass/) has been used for spatio-temporal analysis for the period 1989-2010. Species wise mangrove distribution maps were generated using higher spatial resolution IRS data $(5 \mathrm{~m})$ of 2010. The buffer of $2 \mathrm{~km}$ region is considered essentially to know the status of the estuary and its environs which have direct influence on the ecology of the estuary. Accuracy assessment of the classified remote sensing data was done to assess the quality of the information derived from remote sensed data by a set of reference pixels. The number of reference pixels are considered for each land use class is an important factor in determining the accuracy of the classification. These field data was overlaid on the species wise classified image, where each pixel can be considered to represent the dominant class in the region. Classification accuracy was determined using three complementary measures which are based on error matrices derived from independent field data. These test samples are then used to generate the error matrix (also referred as confusion matrix), kappa ( $\kappa$ ) statistics and producer's (PA) and user's accuracies (UA) to assess the classification accuracies. An error matrix compares true reference data (from habitats visited in the field) to the habitat types predicted from image classification. The overall accuracy and a Kappa analysis were used to perform classification accuracy assessment. Kappa is an accuracy statistic that permits us to compare two or more matrices and weighs cells in error matrix according to the magnitude of misclassification. Kappa analysis is a discrete multivariate technique used in accuracy assessment [45]. The study provided spatio temporal dynamics of mangroves in the estuarine region, and the species wise mangrove distribution (Figure 2).

\section{Results and Discussion}

Estuary-wise spatio temporal analysis provided insights regarding spatial extent and species composition of mangroves in the estuarine regions with $2 \mathrm{~km}$ buffer.

\section{Aghnashini estuary}

The temporal dynamics of mangroves in the Aghnashini estuary is given in Figure 3 show an increase of vegetation from 40.79 (1989) to $44.92 \%$ (2010) due to reforestation initiatives by the forest department. Table 2 lists the land use details. Intensification of aquaculture

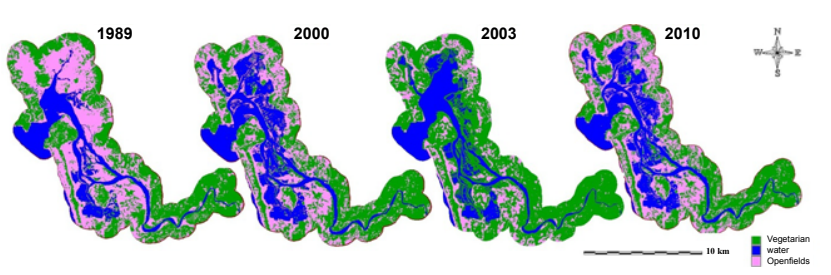

Figure 3: Aghnashini estuary (buffer).

\begin{tabular}{|l|c|c|c|c|c|c|}
\hline \multirow{2}{*}{$\begin{array}{l}\text { Category } \\
\text { Year }\end{array}$} & \multicolumn{2}{|c|}{ Vegetation } & \multicolumn{2}{c|}{ Water } & \multicolumn{2}{c|}{ Open fields } \\
\cline { 2 - 7 } & Ha & $\%$ & Ha & $\%$ & Ha & $\%$ \\
\hline 1989 & 5675.24 & 40.79 & 2643.53 & 19 & 5595.85 & 40.22 \\
\hline 2000 & 5483.63 & 39.41 & 2622.25 & 18.85 & 5808.73 & 41.75 \\
\hline 2003 & 5435.51 & 39.06 & 3988.78 & 28.67 & 4490.32 & 32.27 \\
\hline 2010 & 6250.39 & 44.92 & 3148 & 22.62 & 4516.21 & 32.46 \\
\hline Total area & \multicolumn{4}{|c|}{13914.61} \\
\hline
\end{tabular}

Table 2: Spatio temporal dynamics of Aghnashini estuary (buffer).

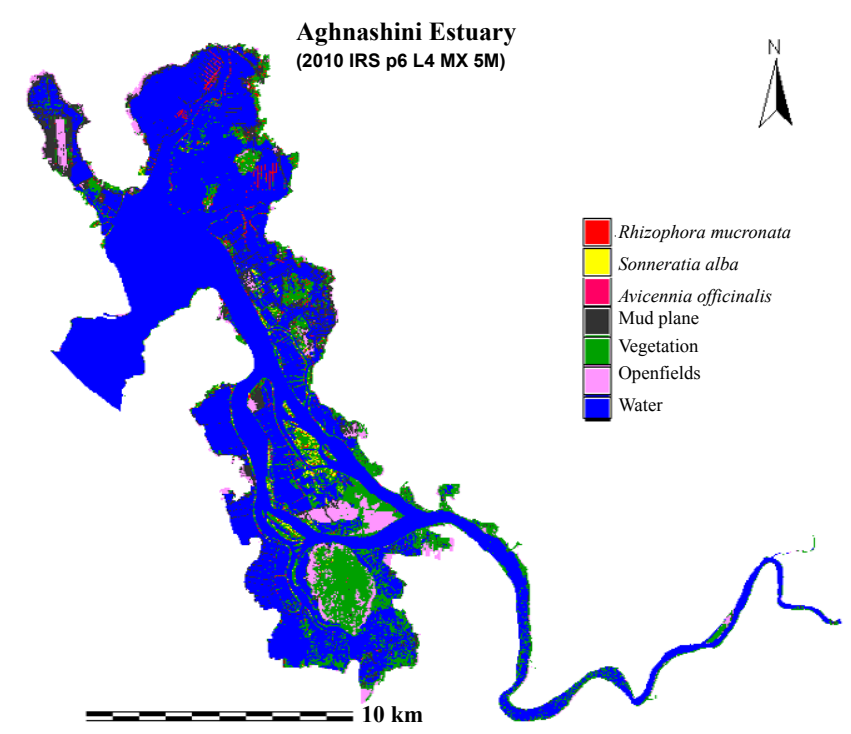

Figure 4: Aghnashini estuary.

during the early 1990's almost wiped the mangroves and open fields were converted as aquaculture ponds. However the failure of shrimp culture in late 90 's led to natural regeneration in the region, especially in undisturbed mud plats. Subsequently, realising the importance of mangroves, village forest committees and state forest department have taken up joint initiative of reforestation with select mangrove species. Aghanashini estuary is having no dams, no notable industrial establishments along its banks and may be considered one of the most pristine ones among the other estuaries of west coast. It is a productive and biologically rich waterscape of coastal Karnataka by its ecosystem goods and services. One of the most notable economic and subsistence output of the Aghanashini estuary is the bivalves (Phylum: Mollusca). The meat of these invertebrates is used as a protein rich food by about 198,000 people along the coastal areas of Karnataka and Goa. Total annual production is 22,006 tons, valued at Rs.57.8 million per annum [39]. Coastal villages situated in close proximity to the estuary characterized by estuarine fishing, and saline tolerant paddy cultivation in ghajini (estuarine agriculture fields) lands (Figure 3) (Table 2). 
Citation: Mesta PN, Setturu B, Subash Chandran MD, Rajan KS, Ramachandra TV (2014) Inventorying, Mapping and Monitoring of Mangroves towards Sustainable Management of West Coast, India. J Geophys Remote Sensing 3: 130. doi:10.4172/2169-0049.1000130

Page 5 of 8

The species wise mangrove distribution is given in Figure 4. Table 3 lists the species, which shows the region is dominated by Rhizophora mucronata (1.45\%) followed by Sonneratia alba (0.65\%), Avicennia officinalis $(0.05 \%)$. Other mangrove associated vegetation (Derris trifoliate, Cyperus malaccensis, Erythrina indica, Ficus racemosa, etc.) and coconut plantations cover about $16.45 \%$. The availability open fields (4.85\%) and mud flats (7.46\%) highlight the opportunity to diversify the effort for effective management. A wide variety and assortments of fish, molluscs, crabs and prawns inhabit here, which are harvested and exported. Mangroves of Aghanashini provides a good roosting place for many species of birds, which find rich food supply in the estuary.

\section{Gangavali estuary}

Figure 5 and Table 4 provide the spatial extent of land uses in Gangavali estuarine region during 1989 to 2010. The vegetation cover has increased from $48.77(1989)$ to $51.59 \%$ (2010) with the decline of open fields. The region contains natural growth of mangrove forests with less monoculture plantations. Owing to the tropical monsoonal

\begin{tabular}{|l|c|c|}
\hline Category & Ha & $\%$ \\
\hline Rhizophora mucronata & 74.27 & 1.42 \\
\hline Sonneratia alba & 33.72 & 0.65 \\
\hline Avicennia officinalis & 5.40 & 0.11 \\
\hline Vegetation & 857.46 & 16.37 \\
\hline Water & 3615.19 & 69.05 \\
\hline Open fields & 259.13 & 4.94 \\
\hline Mud plane & 390.83 & 7.46 \\
\hline Total area & & \\
\hline
\end{tabular}

Table 3: Species wise distribution of Aghnashini estuary.

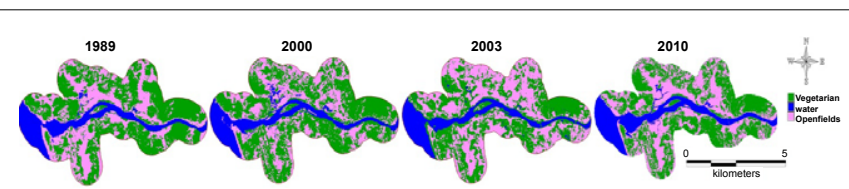

Figure 5: Gangavali estuary (buffer)

\begin{tabular}{|l|c|c|c|c|c|c|}
\hline \multirow{2}{*}{$\begin{array}{l}\text { Category } \\
\text { Year }\end{array}$} & \multicolumn{2}{|c|}{ Vegetation } & \multicolumn{2}{c|}{ Water } & \multicolumn{2}{c|}{ Open fields } \\
\cline { 2 - 7 } & $\mathbf{H a}$ & $\mathbf{\%}$ & Ha & $\%$ & Ha & $\%$ \\
\hline 1989 & 2280.83 & 48.77 & 715.26 & 15.29 & 1680.46 & 35.93 \\
\hline 2000 & 2389.58 & 51.1 & 723.12 & 15.46 & 1563.85 & 33.44 \\
\hline 2003 & 2348.34 & 50.22 & 783.66 & 16.76 & 1544.54 & 33.02 \\
\hline 2010 & 2413.09 & 51.59 & 831.24 & 17.77 & 1432.24 & 30.64 \\
\hline Total area & \multicolumn{4}{|c|}{$\mathbf{4 6 7 6 . 5 5}$} \\
\hline
\end{tabular}

Table 4: Spatio temporal dynamics of Gangavali estuary (buffer).

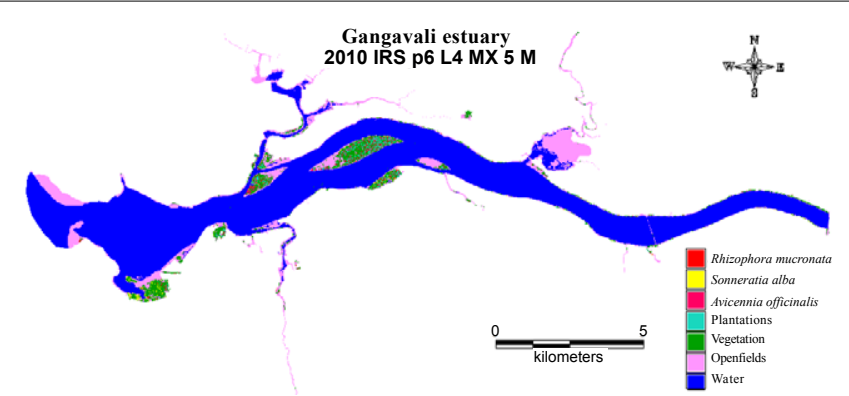

Figure 6: Gangavali estuary. climate, there is intense weathering of the hinterland, and transportation of weathered materials to the coastal environment is causing tiny sand bars. Gangavali estuary is the common breeding place for native species of penaeid prawns viz., Penaeus indicus, $P$. merguiensis, $P$. monodon and Metapenaeus dobsoni, which are providing major lively hood for the local fishermen.

Species wise distribution (Figure 6 and Table 5) shows that the region consists of Rhizophora mucronata (3.010 Ha), Avicennia officinalis (2.088 Ha), Sonneratia alba (1.903 Ha). Avicenna and Sonneratia species grows naturally here. Realizing the importance of mangroves, agrarians have started planting on the embankments, which protects their farmlands with the entangled roots against breaches. The river mouth has good patch dominated by Sonneratia alba. Though mangrove habitats are few, all along the edge of the river linear strip is found. Some small good patches occur at Bilihonge and Agragone villages.

\section{Sharavathi estuary}

Figure 7 depicts the Sharavathi estuary dynamics during 1989 to 2010.The Sharavathi River has a catchment area of $3600 \mathrm{sq} . \mathrm{km}$. The spatio temporal dynamics as listed in Table 6 indicate the decline open fields from $28.28 \%$ to $26.09 \%$ due to enhanced agricultural activities. Non-mangroves plantations have increased in this region, evident from the conversion of open fields for coconut or other cash crop cultivations. Increase in vegetation cover from $59.7 \%$ to $60.49 \%$ is due to the plantation activities. The continuous discharge of freshwater with the construction of dams and reservoirs has changed flora and faunal dynamics in this estuary.

The mangroves species distribution (Figure 8) shows that this region is dominated by natural growth of Sonneratia caseolaris followed

\begin{tabular}{|l|c|c|}
\hline Category & Ha & $\%$ \\
\hline Rhizophora mucronata & 3.010 & 0.46 \\
\hline Sonneratia alba & 1.903 & 0.29 \\
\hline Avicennia officinalis & 2.088 & 0.32 \\
\hline Vegetation & 36.465 & 5.58 \\
\hline Water & 500.146 & 76.6 \\
\hline Open fields & 102.622 & 15.72 \\
\hline Plantation & 6.693 & 1.03 \\
\hline Total area & \multicolumn{2}{|c|}{$\mathbf{6 5 2 . 9 2 7}$} \\
\hline
\end{tabular}

Table 5: Species wise distribution of Gangavali estuary.

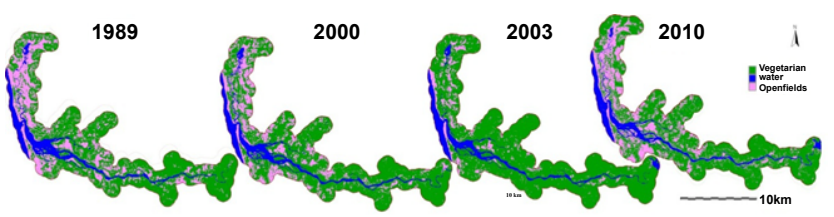

Figure 7: Sharavathi estuary (buffer).

\begin{tabular}{|l|c|c|c|c|c|c|}
\hline \multirow{2}{*}{$\begin{array}{l}\text { Category } \\
\text { Year }\end{array}$} & \multicolumn{2}{|c|}{ Vegetation } & \multicolumn{2}{c|}{ Water } & \multicolumn{2}{c|}{ Open fields } \\
\cline { 2 - 7 } & Ha & $\%$ & Ha & $\%$ & Ha & $\%$ \\
\hline 1989 & 11111.37 & 59.7 & 2237.26 & 12.02 & 5263.12 & 28.28 \\
\hline 2000 & 11049.27 & 59.37 & 2264.91 & 12.17 & 5297.56 & 28.46 \\
\hline 2003 & 11076.47 & 59.51 & 2046.44 & 11 & 5488.85 & 29.49 \\
\hline 2010 & 11258.78 & 60.49 & 2497.86 & 13.42 & 4855.12 & 26.09 \\
\hline
\end{tabular}

Total area 18611.75

Table 6: Spatio temporal dynamics of Sharavathi estuary (buffer) 


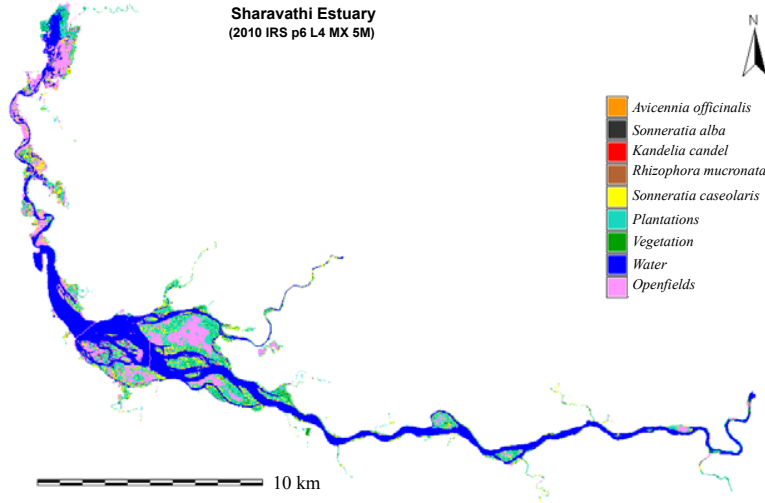

Figure 8: Sharavathi estuary.

\begin{tabular}{|l|c|c|}
\hline Category & Ha & $\%$ \\
\hline Avicennia officinalis & 10.70 & 0.31 \\
\hline Sonneratia alba & 23.00 & 0.67 \\
\hline Kandelia candel & 6.81 & 0.20 \\
\hline Rhizophora mucronata & 5.41 & 0.16 \\
\hline Sonneratia caseolaris & 81.96 & 2.40 \\
\hline Plantations & 219.65 & 6.44 \\
\hline Vegetation & 515.21 & 15.08 \\
\hline Water & 1334.90 & 39.08 \\
\hline Open fields & 1218.12 & 35.66 \\
\hline Total area & & \\
\hline
\end{tabular}

Table 7: Species wise distribution of Sharavathi estuary.

by other mangrove species like Sonneratia alba, Kandelia candel (Table 7). All species present in the region other than Sonneratia caseolaris are due to the extensive reforestation activities. The presence of moderate salinity favorable species is due to lowered salinity levels in the estuary due to the continuous flow of fresh water from the reservoir. The mangroves associated with higher salinity, such as Rhizophora spp., Avicennia marina, Sonneratia alba etc. have vanished almost totally in the lower part of estuary. Plantations other than mangroves constitute $20.53 \%$ of the estuarine region. The Sonneratia caseolaris also grows well around the river, islands and contributes to some extent the firewood needs of the locals. The region is mainly facing a threat due to the large scale anthropogenic activities involving conversion of land for cash crops and coconut plantations. This necessitates constant vigil through regular monitoring to minimize the impacts of human induced disturbances.

\section{Venkatapura estuary}

Venkatapura estuary is the smallest among all other estuaries in the district and a submerged bar developed due to confluence sedimentation that modify the wave pattern from west. The spatio temporal changes (Figure 9 and Table 8) show the increase in the vegetation cover from 28.2 (1989) to $33.95 \%$ (2010) and decrease in the open fields. Coastal erosion is posing serious challenges due to syncronisation of flash flood in the river and strong wave activities during south west monsoon. The loss of native vegetation along the estuary is the principal reason for erosion. Due to the heavy human impact from the densely populated places like Bhatkal and Shirali as well as due to the smallness of the estuary, this region lacks significant mangrove cover. The species wise distribution map shows Sonneratia alba is the most dominant species among all (Figure 10 and Table 9). Parallel to the coast, approximately at $2 \mathrm{~m}$ depths and at the confluence of the river mouth of the Venkatapur, concentric submerged bar is developed. The availability of $34.38 \%$ open fields shows that there are ample chances for reforestation of mangrove species. This estuary has good oyster deposits.

Accuracy assessment is done through the computation of overall (OA), user's (UA) and producer's (PA) accuracies and Kappa coefficient. Training sites and transects data ensures the independence of the reference data for species mapping. Tables 10a and 10b provides the accuracy details of the study. Accuracy assessment for species wise mapping also shows greater overall accuracy and Kappa statistic. The integration of ground based field monitoring with the remote

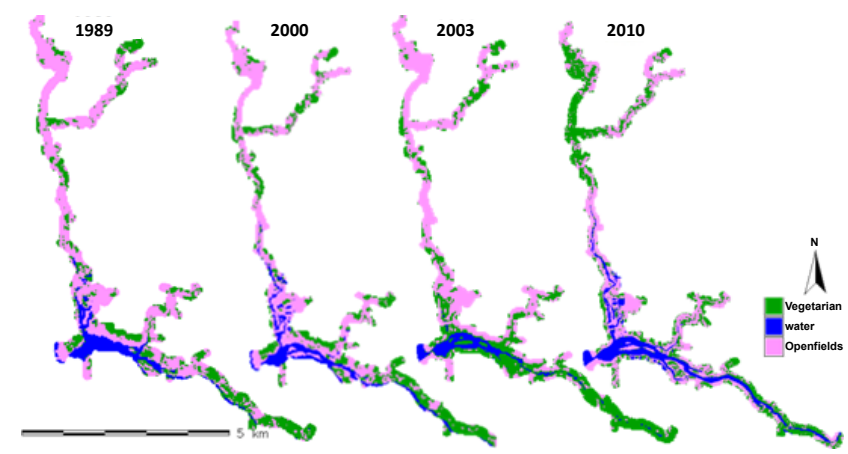

Figure 9: Venkatapura estuary (buffer)

\begin{tabular}{|l|c|c|c|c|c|c|}
\hline \multirow{2}{*}{$\begin{array}{l}\text { Category } \\
\text { Year }\end{array}$} & \multicolumn{2}{|c|}{ Vegetation } & \multicolumn{2}{c|}{ Water } & \multicolumn{2}{c|}{ Open fields } \\
\cline { 2 - 8 } & Ha & \% & Ha & \% & Ha & $\%$ \\
\hline 1989 & 226.17 & 28.2 & 87.84 & 10.95 & 488.07 & 60.85 \\
\hline 2000 & 243.54 & 30.36 & 84.87 & 10.58 & 473.67 & 59.06 \\
\hline 2003 & 269.36 & 33.58 & 55.98 & 6.98 & 476.74 & 59.44 \\
\hline 2010 & 272.33 & 33.95 & 125.36 & 15.63 & 404.39 & 50.42 \\
\hline Total area & \multicolumn{4}{|c|}{$\mathbf{8 0 2 . 0 8}$} \\
\hline
\end{tabular}

Table 8: Spatio temporal dynamics of Venkatapura estuary (buffer).

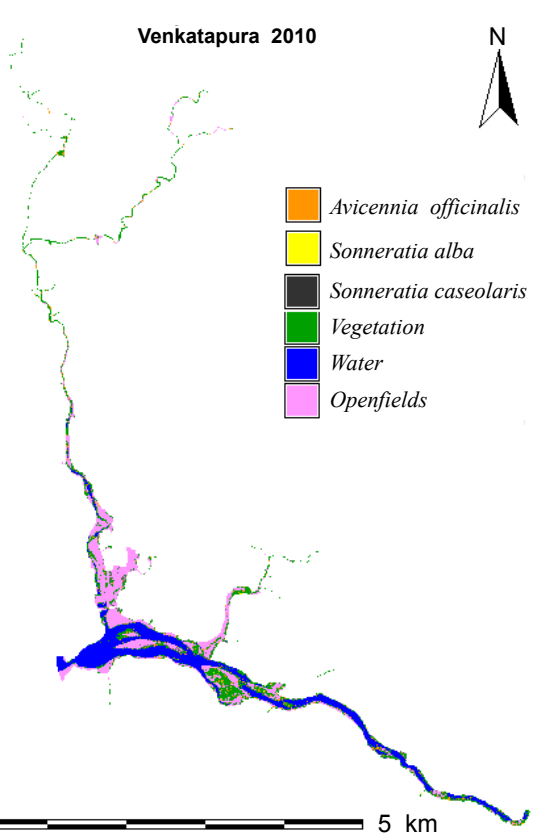

Figure 10: Venkatapura estuary. 


\begin{tabular}{|l|c|c|}
\hline Category & Ha & $\%$ \\
\hline Avicennia officinalis & 9.88 & 4.53 \\
\hline Sonneratia alba & 5.61 & 2.57 \\
\hline Sonneratia caseolaris & 0.710 & 0.33 \\
\hline Vegetation & 56.292 & 25.82 \\
\hline Water & 70.572 & 32.37 \\
\hline Open fields & 74.947 & 34.38 \\
\hline Total & & $\mathbf{2 1 8 . 0 0 9}$ \\
\hline
\end{tabular}

Table 9: Species wise distribution of Venkatapura estuary.

\begin{tabular}{|c|c|c|}
\hline Year & Overall Accuracy & Kappa \\
\hline $\mathbf{1 9 8 9}$ & 83.39 & 0.81 \\
\hline $\mathbf{2 0 0 0}$ & 84.85 & 0.80 \\
\hline $\mathbf{2 0 0 3}$ & 88.26 & 0.82 \\
\hline $\mathbf{2 0 1 0}$ & 91.21 & 0.89 \\
\hline
\end{tabular}

Table 10a: Accuracy assessment from 1989 to 2010

\begin{tabular}{|l|c|c|c|c|}
\hline Category & $\begin{array}{c}\text { Producer's } \\
\text { Accuracy }\end{array}$ & $\begin{array}{c}\text { User's } \\
\text { Accuracy }\end{array}$ & $\begin{array}{c}\text { Overall } \\
\text { Accuracy }\end{array}$ & Kappa \\
\hline Avicennia officinalis & 88.53 & 96.13 & & \\
\hline Sonneratia alba & 98.09 & 80.05 & & \multirow{2}{*}{0.89} \\
\cline { 1 - 2 } Kandelia candel & 94.58 & 82.65 & \multirow{2}{*}{90.89} & \\
\cline { 1 - 2 } Rhizophora mucronata & 86.50 & 93.84 & & \\
\hline Sonneratia caseolaris & 96.65 & 89.52 & & \\
\hline
\end{tabular}

Table 10b: Species wise accuracy assessment.

sensing data provided species level spatial distribution of mangroves. Training sites of exclusive species referred to mangrove tree species that restricted to the mangrove habitat were selected for the most common species encountered in the mangrove regions. Other species which did not form enough mono specific patches for training site selection are considered as other vegetation types. The improvement can be achieved in future by incorporating new high resolution remote sensing data for further analysis. Rate of expansion, indicates the mangrove's ability to occupy new habitats. However degradation of mangrove habitats due to anthropogenic activities has contributed the decline in some pockets. The available open fields clearly illustrate the opportunity for effective management activities. Planting of Avicennia marina, Avicennia officinalis saplings of high salt tolerates $(>25 \mathrm{ppt}$ (parts-per trillion)) are suggested in the seaward end of estuaries where the freshwater discharge is low. Mangrove plant species of Rhizophora apiculata, Kandelia candel, Acanthus ilicifolius species are appropriate to be planted in seaward areas of estuaries and lagoons in the wet zone of moderate salinity tolerance (15-25 ppt). Mangrove plant species of low salinity tolerance ( $<15 \mathrm{ppt})$ Sonneratia caseolaris, Sonneratia alba, Excoecaria agallocha plants are suitable to be planted in the upper reaches of estuaries with high freshwater input (wet zone). The plantation of Avicennia marina \& Avicennia officinalis are prompted in Aghnashini, Ganagavali estuaries due to their excellence in source of honey production. Apiculture has to be promoted in mangrove areas, which assists the dual purpose of increasing area under mangroves and to increase honey production.

\section{Conclusion}

Mangrove ecosystems play a vital role in the coastal ecosystems through the bio-geochemical cycling and also in supporting the livelihood. Reclaiming estuarine areas has become rampant from past three decades due to human habitation, agriculture and horticulture in substantial areas along the coast causing considerable destruction of mangrove cover. The analysis of spatio-temporal dynamics provided the details of spatial extent apart from providing the species level information. This gives an opportunity for a better understanding of mangrove ecosystems and plan towards its sustainable resource management. A distinction of mangrove and non-mangrove areas has been done through high spatial resolution IRS multi spectral data $(5 \mathrm{~m})$. Supervised classification through GMLC provided details of categories primarily on stocking density of mangroves. In addition, the species wise distribution of mangroves has provided an insight of spatial variability of species. The information on the status and spatial distribution of mangrove forest cover at species level in Honnavar division will aid forest managers, conservators and decision makers for effective mangroves management. This helped to realize the opportunities provided the development schemes for the conservation and restoration of mangrove forests in the region. Harvest restrictions, conservation areas, replanting, public education, and permits for timber harvesting are currently the principal approaches to mangrove conservation and sustainable use in Honnavar forest division. Management issues should be addressed by use of a strategic planning process by providing legislative protection to develop clear policy directions for mangroves which includes the estuary and catchment area as a combined ecological unit so that processes underlying vegetation changes are understood and actions can be better targeted. It's evident and well accepted that; the role of mangrove vegetation in protecting coastal biodiversity is irreplaceable. So, there is a need for a long-term preventive approach to prevent the causes of mangrove degradation and resolve the conflicts among competing users of mangrove resources taking into consideration the needs of future generation and of nature. The sustainable use of mangroves is to be promoted to reap the economic benefits of mangroves by local communities that motivates conservation by the local people.

\section{Acknowledgement}

We are grateful to Honnavar Forest division; the Ministry of Environment and Forests, Government of India; NRDMS division, the Ministry of Science and Technology Government of India for the financial assistance; Indian Institute of Science for providing infrastructure; National Remote Sensing Center (NRSC) Hyderabad for providing the satellite data.

\section{References}

1. Suratman $M N(2008)$ Carbon sequestration potential of mangroves in Southeast Asia. Managing Forest Ecosystems 17: 297-315.

2. Simard M, Rivera-Monroy VH, Mancera-Pineda JE, Castañeda-Moya E, Twilley RR (2008) A systematic method for 3D mapping of mangrove forests based on Shuttle Radar Topography Mission elevation data, ICEsat/GLAS waveforms and field data: Application to Cienaga Grande de Santa Marta, Colombia Remote Sensing of Environment 112: 2131-2144.

3. Woodroffe C (1992) Mangrove Sediments and Geomorphology

4. Naylor RL, Goldburg RJ, Primavera JH, Kautsky N, Beveridge MCM, et al., (2000) Effect of aquaculture on world fish supplies. Nature 405: 1017-1024.

5. Zhang Q, Shuzhen S (2001) The mangrove wetland resources and their conservation in China. Journal of Natural Resources 16: 28-36.

6. Walters BB, Ronnback P, Kovacs JM, Crona B, Hussain SA, et al., (2008) Ethnobiology, socio-economics and management of mangrove forests: $A$ review. Aquat Bot 89: 220-236.

7. Costanza Robert, Ralph D'arge, Rudolf De Groot, Tephen Farber Monica Grasso, et al., (1997) The valuation of world's ecosystem services and natural capital. Nature 387: 253-260.

8. UNEP-WCMC (2006) Shoreline protection and other ecosystem services from mangroves and coral reefs. Cambridge, UK

9. Boullion S, Borges AV, Castaneda-Moya E, Diele K, Dittmar T, et al., (2008) Mangrove production and carbon sinks: A revision of global budget estimates. Glob Biochem Cycles 22: 1-12. 
Citation: Mesta PN, Setturu B, Subash Chandran MD, Rajan KS, Ramachandra TV (2014) Inventorying, Mapping and Monitoring of Mangroves towards Sustainable Management of West Coast, India. J Geophys Remote Sensing 3: 130. doi:10.4172/2169-0049.1000130

10. Donato DC, Kauffman JB, Murdiyarso D, Kurniato S, Stidham M, et al., (2011) Mangroves among the most carbon-rich forests in the tropics. Nature Geoscience 4: 293-297.

11. Britta S, Jane M, Duke NC (2005) Water quality in the Great Barrier Reef region: responses of mangrove, sea grass and macro algal communities. Marine Pollution Bulletin 51: 279-296.

12. McKee KL (2005) Global change impacts on mangrove ecosystems

13. Duke NC, Burns KA (2003) Fate and effects of oil and dispersed oil on mangrove ecosystems in Australia. In environmental implications of offshore oil and gas development in Australia: further research. A compilation of three scientific marine studies Australian Petroleum Production and Exploration Association (APPEA), Canberra 232-363.

14. Eslami-Andargoli L, Dale PER, Chaseling JNS (2010) Local and landscape effects on spatial patterns of mangrove forest during wetter and drier periods: Moreton Bay, Southeast Queensland, Australia. Estuarine Coastal and Shelf Science 89: 53-61.

15. Hauff RD, Ewel KC, Jack J (2006) Tracking human disturbance in mangroves: estimating harvest rates on a Micronesian island. Wet Ecol Manage 14: 95-105.

16. Giri C, Pengra B, Zhu Z, Singh A, Tieszen LL (2007) Monitoring mangrove forest dynamics of the Sundarbans in Bangladesh and India using multitemporal satellite data from 1973 to 2000 . Estuarine Coastal and Shelf Science 73: $91-100$.

17. Pattanaik C, Prasad SN (2011) Assessment of aquaculture impact on mangroves of Mahanadi delta (Orissa), East coast of India using remote sensing and GIS. Ocean \& Coastal Management 54: 789-795.

18. Kairo JG, Kivyatu B, Koedam N (2002) Application of remote sensing and GIS in the management of mangrove forests within and adjacent to Kiunga Marine Protected Area, Lamu, Kenya. Environment Development and Sustainability 4: 153-166.

19. Li X, Yeh AGO, Liu K, Wang S (2006) Inventory of mangrove wetlands in the Pearl River Estuary of China using remote sensing. Journal of Geographical Sciences 2: 155-164

20. Adam E, Mutanga O, Rugege D (2010) Multispectral and hyperspectra remote sensing for identification and mapping of wetland vegetation: a review. Wetlands Ecology Management 18: 281-296.

21. Bharath Setturu, Rajan KS, Ramachandra TV (2013) Land Surface Temperature Responses to Land Use Land Cover Dynamics.

22. Ramachandra TV, Bharath Setturu, Bharath Aithal H (2014) Spatio-temporal dynamics along the terrain gradient of diverse landscape. Journal of Environmental Engineering and Landscape Management 22: 50-63.

23. Fabbri KP (1998) A methodology for supporting decision making in integrated coastal zone management. Ocean and Coastal Management 39: 51-62.

24. Green EP, Mumby PJ, Edwards AJ, Clark CD (2000) Remote sensing handbook for tropical coastal management.

25. Bharath Setturu, Bharath Aithal H, Rajan KS, Ramachandra TV (2012) Cost effective mapping, monitoring and visualisation of spatial patterns of urbanisation using FOSS.

26. Reis-Neto AS, Cunha-Lignon M, Reis Filho AS, Meireles AJA (2012) Analyses of the mangrove's recover process in abandoned salt pounds constructed areas, in the Ceara river, Northeast Brazil. VLIZ Special Publication 57: 155.

27. Vaiphasa C, Skidmore AK, de Boer WF (2006) A post-classifier for mangrove mapping using ecological data. ISPRS J Photogramm Remote Sens 61: 1-10.

28. Prasad PR, Reddy CS, Rajan KS, Raza SH, Dutt CBS (2009) Assessment of tsunami and anthropogenic impacts on the forest of the North Andaman Islands, India. International Journal of Remote Sensing 30: 1235-1249.

29. Kovacs JM, Liu Y, Zhang C, Flores-Verdugo F, Flores-de-Santiago J (2011) A field based statistical approach for validating a remotely sensed mangrove forest classification scheme. Wetlands Ecology Management 19: 409-421.

30. Ramsey EWIII, Jensen JR (1996) Remote sensing of mangrove wetlands: Relating canopy spectra to site-specific data. Photogrammetric Engineering and Remote Sensing 62: 939-948.

31. Liu K, Li X, Shi X, Wang S (2008) Monitoring mangrove forest change using remote sensing and GIS data with decision-tree learning. Wetlands 28: 336-346.
32. Giri C, Ochieng E, Tieszen LL, Zhu Z, Singh A, et al., (2010) Status and distribution of Mangrove forests of the world using earth observation satellite data. Global Ecology and Biogeography 20: 154-159.

33. Everitt JH, Yang C, Sriharan S, Judd FW (2008) Using High Resolution Satellite Imagery to Map Black Mangrove on the Texas Gulf Coast. Journal of Coastal Research 246: 1582-1586.

34. Green EP, Clark CD, Mumby PJ, Edwards AJ, Ellis AC (1998) Remote sensing techniques for mangrove mapping. International Journal of Remote Sensing 19: $935-956$.

35. Saito H, Bellan MF, Al-Habshi A, Aizpuru M, Blasco F (2003) Mangrove research and coastal ecosystem studies with SPOT-4 HRVIR and TERRA ASTER in Arabian Gulf. International Journal of Remote Sensing 24: 40734092.

36. Gao JA (1999) Comparative study on spatial and spectral resolutions of satellite data in mapping mangrove forests. International Journal of Remote Sensing 20: 2823-2833.

37. Tong PH, Auda Y, Populus J, Aizpura M, Habshi AA, et al., (2004) Assessment from space of mangroves evolution in the Mekong Delta; in relation to extensive shrimp farming. International Journal of Remote Sensing 25: 4795-4812.

38. Kuenzer C, Bluemel A, Gebhardt S, Quoc TV, Dech S (2011) Remote sensing of mangrove ecosystems: A review. Remote Sensing 3: 878-928.

39. Subash Chandran MD, Prakash Mesta, Boominathan M, Rao GR, Vishnu DM et al., (2012) Aghanashini Estuary in Kumta Taluk, Uttara Kannada - Biological Heritage Site, ENVIS Technical Report 35, Energy \& Wetlands Research Group, Centre for Ecological Sciences, Indian Institute of Science, Bangalore, India.

40. Ramachandra TV, Savitha G (2007) Vegetation analysis in Uttara Kannada district using GIS and Remote sensing techniques.

41. Yuan $X(2008)$ A novel method of systematic error compensation for a position and orientation system. Progress in Nature Science 18: 953-963.

42. Satyanarayana B, Raman AV, Mohd-Lokman H, Dehairs F, Sharma VS, et al., (2009) Multivariate methods distinguishing mangrove community structure of Coringa in the Godavari delta, east coast of India. Aquatic Ecosystem Health and Management 12: 401-408

43. Buiten HJ (1988) Matching and mapping of remote sensing images: aspects of methodology and quality.

44. Jixian Zhang, Yonghong Zhang (2007) Remote sensing research issues of the National Land Use Change Program of China. ISPRS Journal of Photogrammetry and Remote Sensing 6: 461-472.

45. Jensen JR (1996) Introductory Digital Image Processing: a Remote Sensing Perspective. Prentice-hall Series in Geographic Information Science, Upper Saddle River, New Jersey, USA. 